\title{
A Survey Of Professor Acceptance And Use Of E-Textbooks In Higher Education
}

\author{
Randy Brown, Ph.D., University of Mary Hardin-Baylor, USA
}

\begin{abstract}
As electronic books (e-books) have continued to gain in popularity, more and more books are becoming available in electronic format. Textbooks are no exception. More and more publishers are making textbooks available in electronic format (e-textbooks). There have been many devices specifically designed to use e-books and e-textbooks with many more devices which utilize e-book apps to further increase the availability and ease of moving to e-books. Many professors are embracing the new technology, but others are somewhat (very, in many cases) resistant. This study discusses a recent study of professor acceptance and intention to use e-textbooks in the classroom and presents preliminary results and conclusions suggested by the survey.
\end{abstract}

Keywords: e-Books; e-Textbooks; e-Readers; Higher Education; Technology Acceptance

\section{INTRODUCTION}

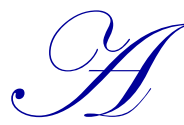

s e-readers and e-books have become more and more accepted, a move has begun to replace paper textbooks with e-textbooks (Rickman, Von Holzen, Klute, \& Tobin, 2009; Steinle, 2006). This has met with mixed results with some successful (Donnelly \& Connolly, 2009; Nie, Armellini, Witthaus, \& Barklamb, 2011) and some not so successful (Barber, 2011; Gregory, 2008) studies or implementations of textbooks in higher education. Libraries seem to have better luck (Hapel, 2012; Nicholas, 2012), but even here, success is not universal (Harrell, 2012; Lonsdale \& Armstrong, 2001).

There have been several studies about students and their acceptance of e-books as replacements for paper textbooks (Gregory, 2008; Walton, 2007) with mixed results. Some studies have included professors (Huang \& Huang, 2004; Wilson, Landoni, \& Gibb, 2002), but there are few, if any, that investigate whether professors will accept e-textbooks and their associated e-readers into the classroom. This is where the current study comes into play, will Professors accept e-textbooks and related technology?

There are studies about professors accepting new technologies (Park, Lee, \& Cheong, 2007; Walton, 2007), with some suggesting a reluctance to adopt new technologies (Zhang \& Xu, 2011). Theories utilized in these studies include behavioral (Kriek \& Stols, 2010; Teo \& Tan, 2012) and motivational (Ahmad, Madarsha, Zainuddin, Ismail, \& Nordin, 2010; Chen \& Tseng, 2012) theories, but the large majority focus on the Technology Acceptance Model (Park et al., 2007; Walker \& Johnson, 2008). The Task-Technology Fit (TTF) Model (Goodhue \& Thompson, 1995) should also be considered to make sure e-textbooks are really appropriate to the higher education classroom. McCarthy suggests that current e-textbooks and e-reader technology may not be appropriate (McCarthy, 2011).

\section{RESEARCH METHOD}

While many professors seem to be reluctant to accept new technology (Zhang \& Xu, 2011), they still appear to be willing to accept the technology if appropriate (Kriek \& Stols, 2010; Walker \& Johnson, 2008), especially in the higher education classroom. There appear to be two parts to this question. The first is whether professor will accept the technology in general, leading to the Technology Acceptance Model (TAM) and its extensions (Davis, 1989; Venkatesh \& Davis, 2000). The second is whether it is appropriate or not, hence the inclusion of the TTF (Goodhue \& Thompson, 1995). Utilizing these two models and adding common comparison criteria on e-readers (Wikipedia), an electronic survey was developed to gather professor experiences and opinions 
on e-readers, e-books, and their classroom uses as e-textbooks. A group of Information Systems professors examined the survey to ensure face validity of the questionnaire. After IRB approval, the survey was deployed online and approximately 450 professors and adjunct faculty were invited to participate, resulting in 47 usable responses - a bit over $10 \%$ response rate.

\section{DATA ANALYSIS}

An initial analysis of the data collected provides some interesting descriptive statistics. 30 of the 47 (64\%) of the faculty members had used e-books and of those 30, only $8(27 \%)$ indicated they would prefer e-books over paper books. None of them would always choose e-books. 13 (43\%) of the 30 preferred paper over e-books. The remaining indicated no preference. The numbers were a bit lower, but with similar results when it came to the etextbooks over paper textbooks. Only 13 faculty indicated they had experience with e-textbooks, and of those, three (3) stated a preference for e-textbooks - about $23 \%$. Six of the $13(46 \%)$ preferred paper textbooks. Interestingly, of the 34 who had not used e-textbooks, 3 (10\%) suggested they would rather use e-textbooks.

\section{CONCLUSION}

As we press forward with implementing e-textbooks in higher education, we need to take time to see whether we are doing the right thing. Just because we can do something does not mean we should - especially when only a quarter of faculty with experience using e-textbooks would actually prefer them and nearly half want paper textbooks. We need much more research in this area before we jump in over our heads. The research presented here is only the beginning. Much more data was collected and will be analyzed to help determine not just the acceptance of e-textbook technology, but also the fit of e-textbooks into higher education.

\section{ACKNOWLEDGEMENT}

This paper written as part of a study funded by a University of Mary Hardin-Baylor Faculty Development Grant.

\section{AUTHOR INFORMATION}

Randy Brown, Ph.D: Dr. Brown has worked in a variety of Information Technology positions starting with serving seven years in the US Air Force as a Computer Systems Engineer, then moving to civilian life where he has worked for five years as a programmer, technical support specialist, sales application engineer, call center architect, network analyst, manager, and other jobs. His work has taken him around the world to Hong Kong, Australia, Korea, and Germany. Since completing his Ph.D. in Information Systems from the University of Texas in Arlington in 2006, Randy has been teaching Business Computers at the University of Mary Hardin-Baylor, USA. His research interests are eclectic and include anything dealing with technology. Contact information: University of Mary Hardin-Baylor, UMHB Box 8018, 900 College Street, Belton, TX 76513 USA. E-mail: Randy.Brown@umhb.edu

\section{BIBLIOGRAPHY}

1. Ahmad, T. B. T., Madarsha, K. B., Zainuddin, A. M., Ismail, N. A. H., \& Nordin, M. S. (2010). Faculty's Acceptance of Computer Based Technology: Cross-Validation of an Extended Model. Australasian Journal of Educational Technology, 26(2), 268-279.

2. $\quad$ Barber, M. (2011). "You can build it but will they come?" A Trial Implementation of eTextbooks at The College of Law. Legal Information Management, 11(4), 238-240. doi: 10.1017/s1472669611000818

3. Chen, H.-R., \& Tseng, H.-F. (2012). Factors that influence acceptance of web-based e-learning systems for the in-service education of junior high school teachers in Taiwan. Evaluation \& Program Planning, 35(3), 398-406. doi: 10.1016/j.evalprogplan.2011.11.007

4. Davis, F. D. (1989). Perceived Usefulness, Perceived Ease of Use, and User Acceptance of Information Technology. MIS Quarterly, 13(3), 319-340.

5. Donnelly, T., \& Connolly, E. (2009). Opting for success. Information Scotland, 7(1), 11-11.

6. Goodhue, D. L., \& Thompson, R. L. (1995). Task-Technology Fit and Individual Performance. MIS Quarterly, 19(2), 213-236. 
7. Gregory, C. L. (2008). "But I Want a Real Book": An Investigation of Undergraduates" Usage and Attitudes toward Electronic Books. Reference \& User Services Quarterly, 47(3), 266-273.

8. Hapel, R. (2012). The Library as a Place. Public Library Quarterly, 31(1), 48-55. doi: 10.1080/01616846.2012.654737

9. Harrell, J. (2012). Literature of Acquisitions in Review, 2008-9. Library Resources \& Technical Services, 56(1), 4-13.

10. Huang, H.-C., \& Huang, S.-H. (2004). The Feasibility Study of Digitalized Textbooks Published by National Open University. Journal of Educational Media \& Library Sciences, 42(2), 275-312.

11. Kriek, J., \& Stols, G. (2010). Teachers' beliefs and their intention to use interactive simulations in their classrooms. South African Journal of Education, 30(3), 439-456.

12. Lonsdale, R., \& Armstrong, C. (2001). Electronic Books: Challenges for Academic Libraries. Library Hi Tech, 19(4), 332-339.

13. McCarthy, D. (2011). Mobile Perspectives: On E-Books. E-Reading--The Transition in Higher Education. EDUCAUSE Review, 46(2), 20-22.

14. Nicholas, P. T. (2012). e-Learning, e-Books and Virtual Reference Service: The Nexus Between the Library and Education. Journal of Library \& Information Services in Distance Learning, 6(1), 3. doi: 10.1080/1533290x.2012.660877

15. Nie, M., Armellini, A., Witthaus, G., \& Barklamb, K. (2011). How Do E-Book Readers Enhance Learning Opportunities for Distance Work-Based Learners? Research in Learning Technology, 19(1), 19-38.

16. Park, N., Lee, K. M., \& Cheong, P. H. (2007). University instructors' acceptance of electronic courseware: An application of the Technology Acceptance Model. Journal of Computer-Mediated Communication, 13(1), 163-186. doi: 10.1111/j.1083-6101.2007.00391.x

17. Rickman, J. T., Von Holzen, R., Klute, P. G., \& Tobin, T. (2009). A Campus-Wide E-Textbook Initiative. EDUCAUSE Quarterly, 32(2).

18. Steinle, K. (2006). Duke University Press Implements New Pricing Model for the e-Duke Scholarly Collection. Against the Grain, 18(3), 26-28.

19. Teo, T., \& Tan, L. (2012). The Theory of Planned Behavior (TPB) and Pre-service Teachers' Technology Acceptance: A Validation Study Using Structural Equation Modeling. Journal of Technology \& Teacher Education, 20(1), 89-104.

20. Venkatesh, V., \& Davis, F. D. (2000). A Theoretical Extension of the Technology Acceptance Model: Four Longitudinal Field Studies. Management Science, 46(2), 186.

21. Walker, G., \& Johnson, N. (2008). Faculty Intentions to Use Components for Web-Enhanced Instruction. International Journal on E-Learning, 7(1), 133-152.

22. Walton, E. W. (2007). From the ACRL 13th National Conference: E-Book Use Versus Users' Perspective. College \& Undergraduate Libraries, 14(4), 19. doi: 10.1080/10691310802046728

23. Wikipedia. (9/10/2012). Comparison of e-book readers Retrieved 9/12/2012, from http://en.wikipedia.org/wiki/Comparison_of_e-book_readers

24. Wilson, R., Landoni, M., \& Gibb, F. (2002). A user-centred approach to e-book design. Electronic Library, 20(4), 322-330. doi: 10.1108/02640470210438865

25. Zhang, W., \& Xu, P. (2011). Do I Have to Learn Something New? Mental Models and the Acceptance of Replacement Technologies. Behaviour \& Information Technology, 30(2), 201-211. 
NOTES 